\title{
Use, management and local ecological knowledge of Sabal mauritiiformis in the Colombian Caribbean
}

\author{
Viviana Andrade-Erazo ${ }^{1 *}$, Ana Estupiñán-González¹, Néstor García², Rodrigo Bernal ${ }^{3}$, Lauren Raz ${ }^{1}$
} and Gloria Galeano1(†)

\begin{abstract}
The leaves of the palm Sabal mauritiformis constitute the natural material most used for thatching in the Colombian Caribbean region. The leaves and other parts of the plant are also used in other economic and cultural activities on a smaller scale. Through 49 semi-structured interviews and seven days of participant observation, we identified the most relevant biocultural features of its utilization. We documented the current uses, management and local knowledge of this palm in two Colombian rural communities, and identified the value chain for its leaves. We found 25 uses for $S$. mauritiformis, belonging to 11 use categories. The leaves are harvested from wild populations, where the most outstanding management practice is tolerance, consisting of the maintenance of the palms in traditional farming systems, even after the elimination of forest canopy. Leaf marketing results in an organized, simple and regional value chain, mainly linked to tourism. The relevance of this species in the Caribbean was evident in the management modalities, the stock of ecological and technical knowledge that the communities have accumulated, and the structuring of an active marketing, which as a whole has allowed the conservation of this palm, despite the almost total disappearance of its natural habitat. With some adjustments in the practices applied to palms, as appropriate harvest rates, protection from browsing, and agreements on prices in the value chain, the case of $\mathrm{S}$. mauritiiformis in the Caribbean would constitute a model of how use and conservation of native biodiversity can contribute to boost regional economy.
\end{abstract}

Keywords: Leaf Harvest; Non-Timber Forest Products; Palm Thatch; Traditional Management; Value Chain.

\footnotetext{
1 Instituto de Ciencias Naturales, Universidad Nacional de Colombia, Apartado 7945. Bogotá, Colombia.

2 Departamento de Biología, Facultad de Ciencias, Pontificia Universidad Javeriana. Bogotá, Colombia, Carrera 7 \# 40-62

3 Reserva Natural Guadualito, Montenegro, Quindío, Colombia

$\dagger$ Deceased

* Corresponding author. \E-mail address: VA (vyandradee@unal.edu.co), ACEG (huitzilin85@gmail.com), NG (nestor.garcia@javeriana.edu.co), RB (rgbernalg@gmail.com), LR (Iraz@unal.edu.co).
}

\section{SIGNIFICANCE STATEMENT}

In Colombia, most of useful wild palms are extracted from the forest and there are few documented cases of palm management in agricultural landscapes. We present the case of Sabal mauritiiformis, which despite being a wild species, is managed intensively by rural communities, who generate income through a regional market of its leaves, while conserving the palm populations inside their farms. Our goal was to achieve an integral panorama about management of the palm groves and associated local knowledge. Management of this resource with huge relevance for peasant communities can be an example of conservation for other native species that are facing the loss of their natural habitat. Our research of this species contributes to the biocultural research scenario of useful palms in tropical America. 


\section{INTRODUCTION}

The leaves of palms in the genus Sabal have been used for thatching in the Caribbean for over a thousand years (Caballero et al. 2001, 2004; GómezAmador 2003; Pérez and Rebollar 2003; Aguilera-Taylor et al. 2007; Aguilera-Taylor 2009). In Colombia, Sabal mauritiformis (H.Karst) Griseb. and \& H.Wendl. has been used since pre-Hispanic times as one of the most important thatching materials in the Caribbean (Fals-Borda 1979,1986; Betancourt-A. 2008). This use is still important among indigenous communities such as the Zenu people in the departments of Córdoba and Sucre (Carsucre and Cudesac 2007), and it has been incorporated by local peasant communities, who praise the beauty and durability of Sabal leaves, compared to those of other palm species (Sena 1990; Moreno et al. 1993; Cruz et al. 2009; Jiménez-Escobar and Estupiñán-González 2011; JiménezEscobar et al. 2011; Anzellini-García-Reyes 2016).

As with other Sabal species throughout the Caribbean (Caballero et al. 2001, 2004; Joyal 1996; Pérez and Rebollar 2003), the growth of tourism on the northern beaches of Colombia has popularized touristic facilities thatched with leaves of $S$. mauritifformis. Since individuals of $S$. mauritiformis are integrated into agroforestry systems at several places in the region, there is an opportunity to achieve a balance between conservation and market optimization (Galeano et al. 2015; Carsucre and Cudesac 2007; Andrade-Erazo and Galeano 2016). This is a special condition, rarely observed for other palm species in Colombia, and offers an excellent scenario for an agrosilvopastoral system.

The usefulness of management and local ecological knowledge for the conservation of natural resources has been widely recognized, both because they are often the first sources of information derived from observation or experimentation (Raymond et al. 2010), and because active management can determine the viability of such resources over time (Charnley et al. 2007; Torres et al. 2015). Local ecological knowledge encompasses the information that human communities have about the processes that occur in their natural environment, the interactions between organisms, and the practices that are carried out to manage the resources that environment offers (Berkes et al. 2000). The main characteristics of this knowledge are its endogenous origin, its social nature and its dynamic condition (Antweiler 1998; Berkes et al. 2000). Management, on the other hand, includes the harvest of useful parts, the preservation and tolerance of wild individuals in areas that have been transformed by humans, and the deliberate increase of populations of the usable plants (Caballero et al. 1998; Casas et al. 2007).

There are multiple negative impacts that the destructive use of non-timber forest products (NTFP) can represent for wild flora (Arnold and Ruiz 2001; Ticktin 2004; Bernal et al. 2011). Nevertheless, it is possible to plan the most appropriate strategies to maximize the benefits, as well as to reduce the ecological impact of harvest, if the scopes of management (Carvalho and Frazão-Moreira 2011; Casas et al. 2007; Blancas et al. 2013), market characteristics (Valderrama 2011; Isaza et al. 2014), and traditional knowledge (Joyal 1996; Berkes et al. 2000; Ticktin and Johns 2002) are known in detail. In the case of $S$. mauritiformis, the growing interest in the use of its leaves could become the main conservation opportunity for the species (Galeano et al. 2015). 
In Colombia, regulation of the use of NTFP such as the leaves of $S$. mauritiiformis is established in the National Code of Renewable Natural Resources and Environmental Protection (Decree 2811, $12 / 18 / 1974)$, and by the Forest Use Regime (Decree 1791, 10/4/1996). These decrees establish that the users of commercial products of wild flora must obtain permission for its use and extraction. In addition, the law stipulates that a harvest and transport permit must be requested for each load to be mobilized. The entities in charge of issuing the permits in the study area are the Regional Autonomous Corporations (the local environmental authority), which charge a fee for the processing of these permits. In the case of the Department of Atlántico, such fees are fixed in accordance with the Resolution 347 of 2008 of the Corporación Autónoma Regional del Atlántico (CRA), based on the volume of leaves to be used or mobilized.

In this case study we sought to document the use of $S$. mauritiiformis leaves from its extraction to its final use on roofs, as seen in the rural communities of two municipalities in the Department of Atlántico, and to characterize the value chain in the Colombian Caribbean region. For this, we took into account the following aspects: How is the palm stands management? Under what socioeconomic and technical conditions does the leaf trade occur? What ecological features of the species and its populations are known by people who benefit from this resource? This study aims to contribute to the knowledge of this species and its commercialization, to identify the weak points in its use and current management, and to recognize the most appropriate strategies to strengthen them.

\section{MATERIAL AND METHODS}

\section{Study species}

Sabal mauritiiformis is a palm with a solitary stem, $8-25 \mathrm{~m}$ tall. Its crown is spherical and consists of 10-15 costapalmate leaves, supported by petioles 1-2 $\mathrm{m}$ long and 3-4 $\mathrm{cm}$ wide at apex. The leaf blade is ca. $3 \mathrm{~m}$ in diameter, and it is deeply divided in many segments arranged in several planes. The segments are green and lustrous on the upper leaf side and whitish on the underside. It has solitary hermaphroditic flowers arranged in repeatedly branched inflorescences that project beyond leaves. The fruits are spherical, with a thin and brittle, black skin. The seeds are hemispherical, approximately $5 \mathrm{~mm}$ in diameter and light brown in color (Galeano and Bernal 2010). It ranges from central Mexico to southwestern Colombia and Venezuela. In Colombia it is found along the Caribbean plain, where it is common, and in Valle del Cauca, Cundinamarca and Tolima departments, where there are small, local populations (Galeano and Bernal 2010).

\section{Study area}

The study was carried out in the municipalities of Piojó and Juan de Acosta in the Department of Atlántico, in northern Colombia. In Piojó we documented the production of $S$. mauritiiformis leaves, whereas at both municipalities we recorded uses, traditional knowledge and leaf marketing.

Piojó and Juan de Acosta are located about $10^{\circ} 44^{\prime} \mathrm{N}$ and $75^{\circ} 06^{\prime}$ (Figure 1), in a region corresponding to tropical dry forest (bs-T), according to Holdridge's life zones system (Igac 1977), and to Caribbean 


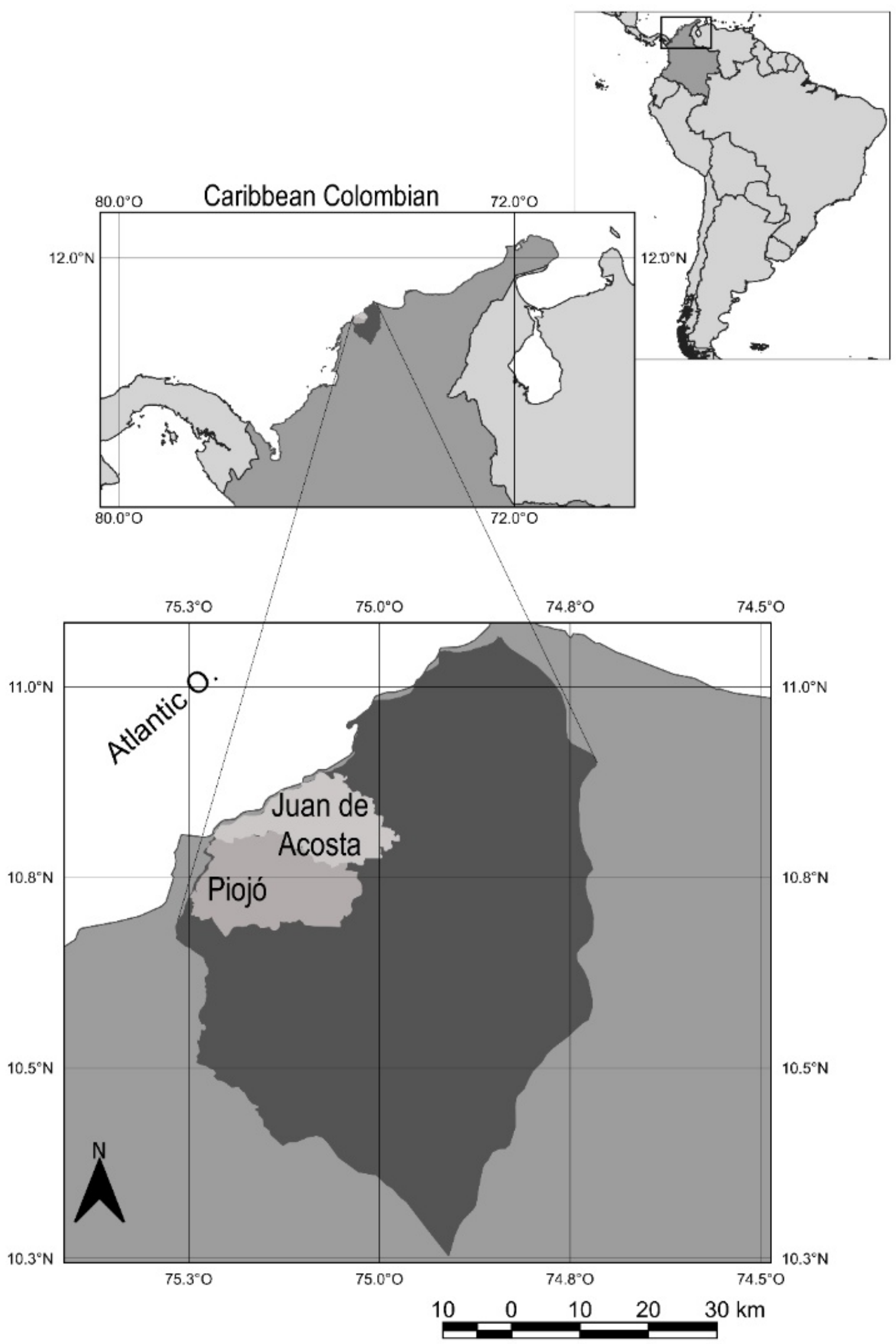

Figure 1. Location of the study area: municipalities surveyed are part of the Deparment of Atlántico, in the Caribbean Region of Colombia. 
tropical dry forest according to Ideam et al. (2007). The area has average annual temperature of $26-28^{\circ} \mathrm{C}$ and an average annual rainfall of $1,500 \mathrm{~mm}$, under a bimodal regime (Ideam 2014). Populations of $S$. mauritiiformis are located mainly on hills, between 269 and 472 m.a.s.l., where a broken relief predominates, with slopes greater than $10 \%$ and well-drained soils supporting shrubs and a thorny herbaceous vegetation, or agricultural crops (AndradeErazo and Galeano 2016).

The inhabitants of these two municipalities are mostly peasants, whose main economic activities are agriculture, cattle farming and subsistence fishing. In Piojó, harvest of Sabal leaves is an important part of the local economy, and in the coastal areas of both municipalities tourism is an important economic activity, especially in Juan de Acosta, whose beaches have become one of the main tourist destinations in the region (Gallardo 2013). In this area there are many touristic facilities thatched with Sabal leaves.

\section{Data collection}

Before fieldwork, we informed people and local authorities about the research project and our objectives, and we asked for permission to gathering information in communitarian meetings and with each person interviewed. Between February and September 2014, we carried out semistructured interviews at both municipalities, with 23 producers, who are owners of palm stands (representing $75 \%$ of all producers in Piojó); four harvesters, who are peasants that cut leaves in return for a payment $(100 \%)$, four thatchers (empajadores) $(100 \%)$, two traders $(100 \%)$, and 18 owners of Sabal-thatched buildings. Producers, harvesters, thatchers and traders were men; women were represented only as owners in five cases. We selected the informants using the snowball technique (Albuquerque et al. 2014) and documented uses of leaves and other plant parts, management actions on palms population and leaves, requirements and processes associated with the production and marketing of leaves.

We gathered information about the socioeconomic status of stakeholders such as age, education level, income sources, farm size, and time spent working with the palms, according to recommendations of Brokamp et al. (2010) and Mayan (2001). For people in direct contact with the palm trees (harvesters, producers, and traders), we also documented their knowledge about factors affecting ecological attributes of the populations, such as density and distribution. With harvesters and thatchers, we carried out seven days of participant observation (Bernard 2011; Albuquerque et al. 2014), of approximately six hours per day, to understand the leaf harvesting and processing up to the final product.

\section{Palm uses and value chain structure}

Information on uses was contrasted and validated with that found in reports and in unpublished technical and academic documents. We classified uses following Macía et al. (2011). Using information about different phases of leaf utilization, we designed a model of the value chain following Kaplinsky and Morris (2002), te Velde et al. (2006) and Valderrama (2011) who propose a structure of five sections (Figure 2).

\section{Management analysis}

We arranged the management practices 


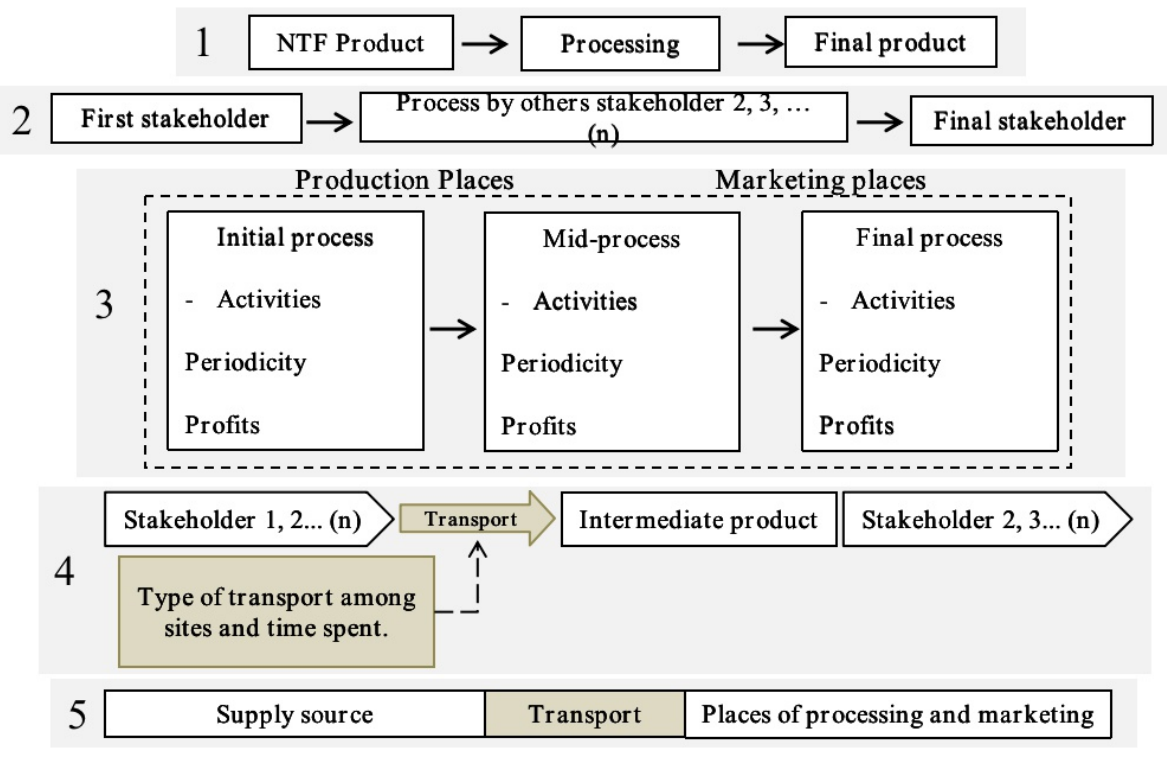

Figure 2. Overall scheme of a value chain for palm NTFP. After Valderrama (2011). The first one section describes the general scheme of the chain; the second one addresses the main stakeholders and steps through the chain; the third represents the marketing channels, assignments for stakeholders, and the work space for each, as well as the income received. The fourth section comprises the relation between source, steps and stakeholders, with the time invested in all process. The fifth one describes the specific geographic areas where the chain components are located.

applied to $S$. mauritiiformis under three categories: tolerance, promotion and protection, as proposed by Casas et al. (2007) and González-Insuasti et al. (2008). We defined tolerance as the presence of individuals that belonged to the natural forest in areas dedicated to agricultural activities; promotion as all the actions aimed at increasing the populations or the availability of the usable resource; and protection, as all those practices that seek to mitigate the damages that biotic and abiotic agents could cause to the palms.

\section{RESULTS}

\section{Common names and uses}

The most widely used name for $S$. mauritiiformis in the Colombian Caribbean is palma amarga (bitter palm). However, other local names include: palmiche in Antioquia (Galeano and Bernal 1987); palma redonda and palmito, in Córdoba (Galeano and Bernal 2010; Jiménez-Escobar and Estupiñán-González 2011), and chingalé or palma chinga in Chimichagua, César (Estupiñán-González 2012).

In the Caribbean of Colombia, $S$. mauritiiformis constitutes an essential, multipurpose resource, contributing to the domestic economy and to the basic needs of rural inhabitants. We documented 25 uses in 11 categories for this palm (Table 1); however, the most cited use was thatching.

\section{Value chain}

Working with Sabal mauritiiformis usually involves men aged 40-70, although in some cases women also take part in commercial activities. Their education level ranges from 
no schooling up to some people with university degrees. Work specialization configures a value chain with five types of stakeholders: producers, traders or middlemen, harvesters, thatchers, and users, each with specific tasks, and interacting among them in a regional market (Figure 3). There were no community organization initiatives for the use of this resource, nor were there any agreements articulating leaf production or marketing. About $90 \%$ of the stakeholders involved in leaf production, harvest and trade were unaware or unclear about the existence of procedures and costs for obtaining use or mobilization permits.

Leaf production comes from wild palms occurring in farms under agricultural use (Figure 4), either in agroforestry and silvopastoral systems, or in areas under regeneration. Productive units range between 2 and 40 ha, most of them in the range of 2 to 10 ha.

According to the palm owners, leaves are suitable for commercialization when they are obtained from stemmed palms, both reproductive and non-reproductive, as well as from acaulescent palms that reach $2 \mathrm{~m}$ in height and whose leaf blade exceeds $1.5 \mathrm{~m}$ in length. The palms are usually harvested once or twice a year, rarely up to 4-6 times a year, and rarely does more than one year pass without harvesting. Based on the number of leaves obtained each year from their palm stands, most producers belong to the category of small or medium producers (Table 2).

Leaf harvest comprises four stages: cutting the leaves, trimming the petioles (espique), piling the leaves, and tieing the bundles. Prior to the day of cutting, the harvester gathers in nearby forests and secondary vegetation the lianas used for binding the leaf bundles. Around $80 \mathrm{~m}$ of vine are required to tie a thousand leaves and the search for this amount requires on average four hours. At least three species of lianas are used: Xylophragma seemannianum (Kuntze) Sandwith (Bignoniaceae) (ají), Seguieria sp., (Phytolaccaceae) (iguana) and an unidentified species (bejuco real).

Leaf harvest is a rigorous work demanding a great physical effort, agility and experience. After reaching the crown with a ladder or climbing the steam, old leaf sheaths and old infructescences must be removed before the leaves cutting. For each palm, harvest takes on average, 3.11 ( \pm 0.43) minutes, including the descent to the ground. Once on the ground, the harvester trims the petiole of each leaf (an activity locally called espique), leaving only a small segment ca. 8-10 cm long. The leaves are left on the ground to dry until the next day. The tools used by harvesters are artisanal, and they include ladders and machetes (Figure 5).

For piling the leaves, the harvesters build a burriquete, which consists of four wooden stakes $2 \mathrm{~m}$ high, sticked in the ground, forming a rectangle ca. $50 \times 78 \mathrm{~cm}$. The harvester gathers groups of 5 leaves (ayuyos), interlacing their segments, then piles 10 ayuyos in the burriquete, and proceeds to tie the whole bundle with two lianas $2 \mathrm{~m}$ long (Figure 5). This process takes an average of $11.41( \pm 0.23)$ minutes. Each pack of 50 leaves is known as a bulto (bundle), which weights ca. $80 \mathrm{~kg}$; two bundles make up a carga (load), the weight a mule can move. The harvester usually works individually, and during 6-8 hours he can cut and trim ca. 1000 leaves. The whole process, including the bundling takes between 2 and 3 days, depending on the ease of movement or transport in the area. When harvesting large volumes of leaves 


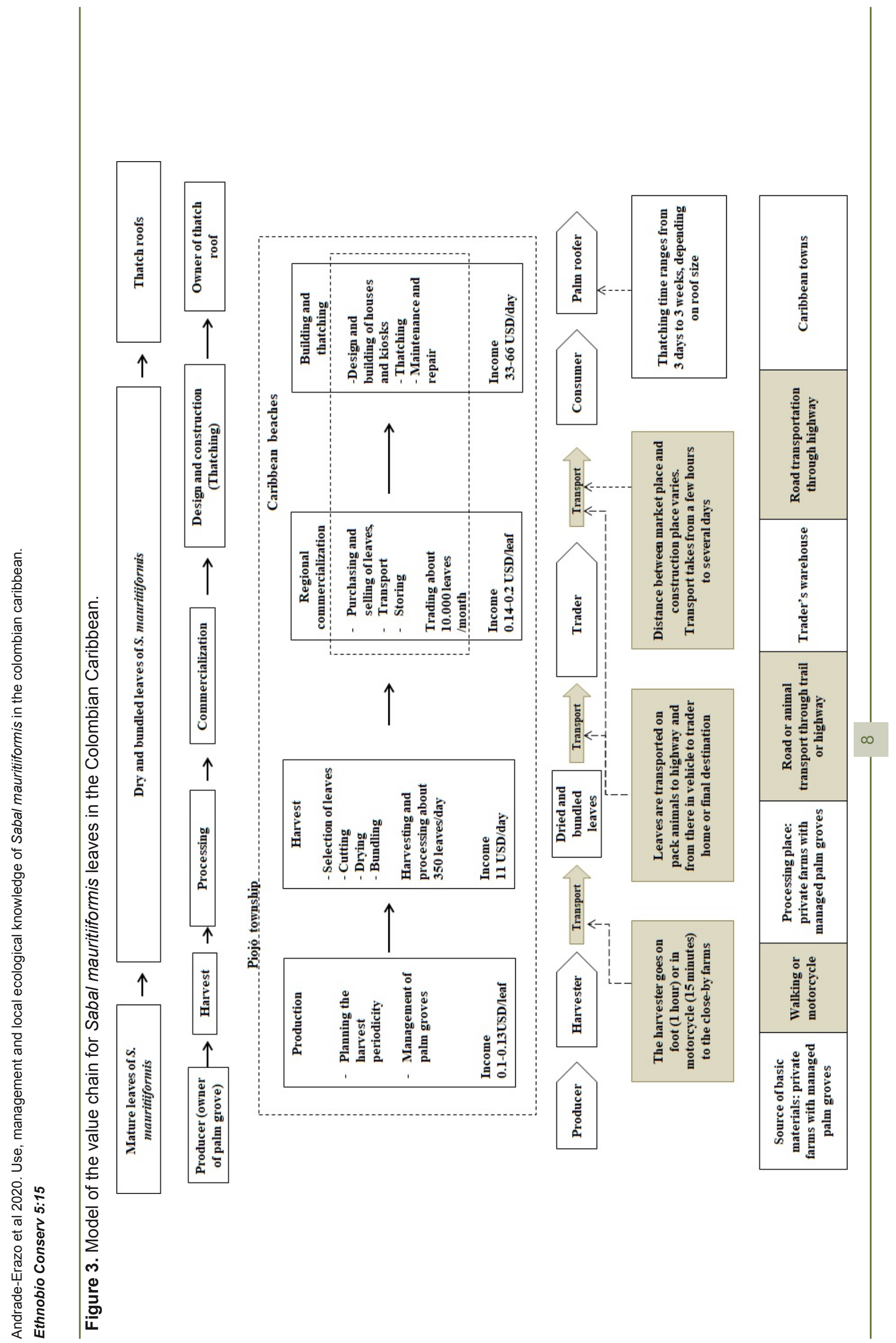









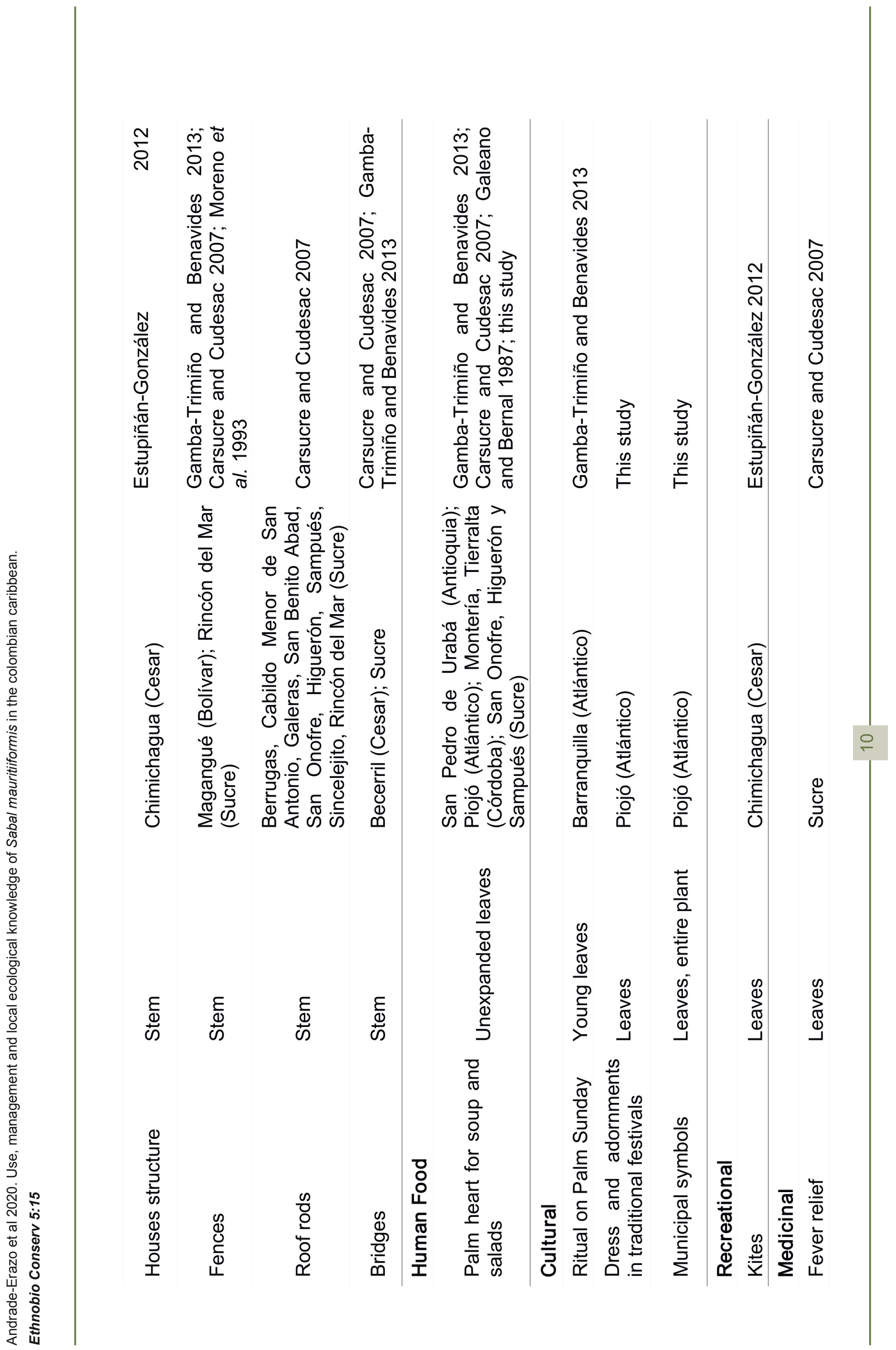




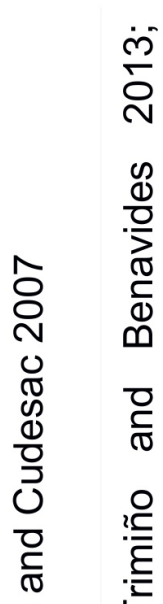

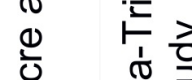

कू है के

Uั

高

$\frac{\sqrt{\bar{J}}}{\overline{\bar{\sigma}}}$

它 峁

㝍

के

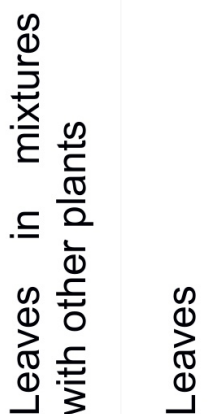

$\stackrel{\infty}{\stackrel{\infty}{5}}$

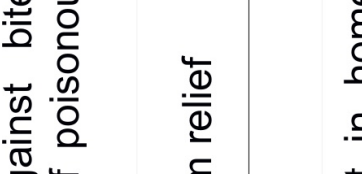

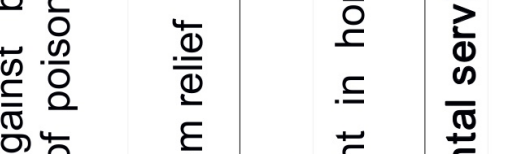

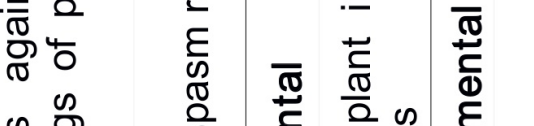

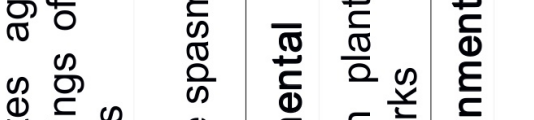

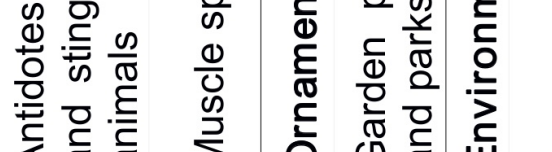

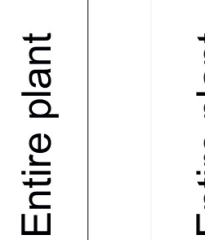

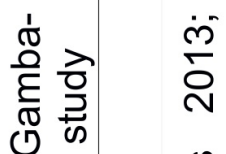

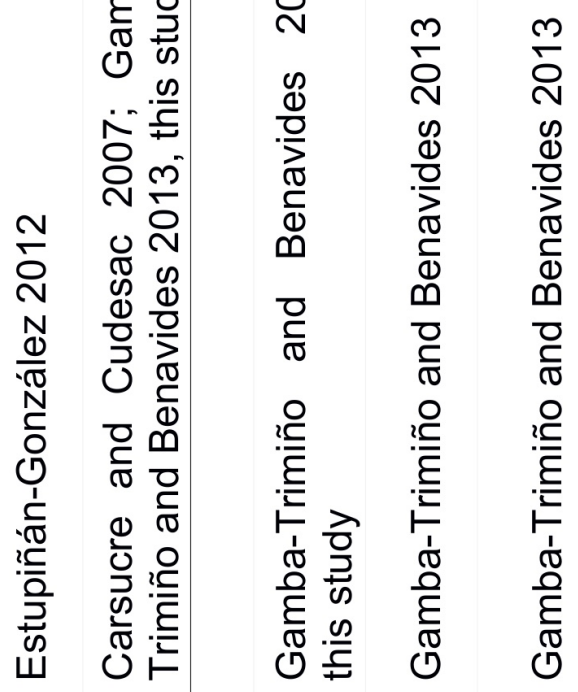

足

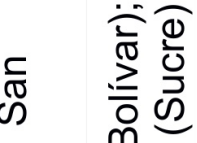

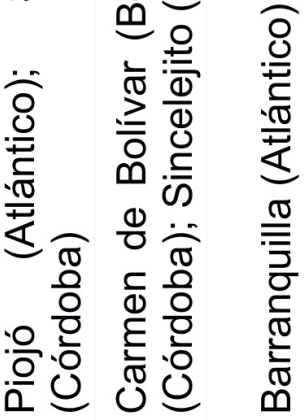

厄్

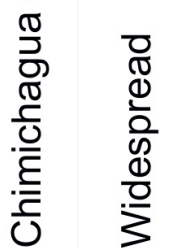

蒿

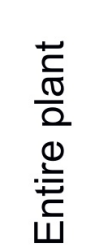

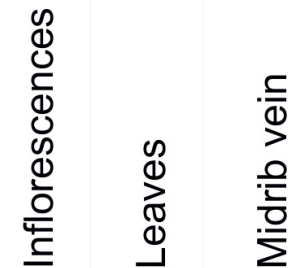

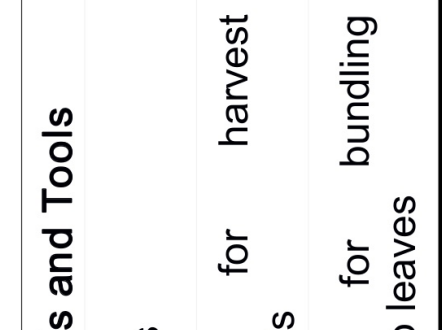

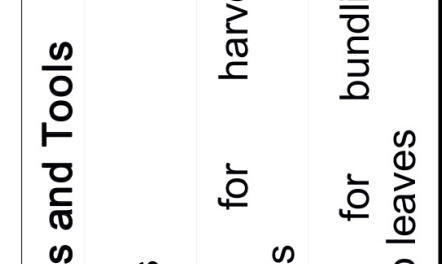

응

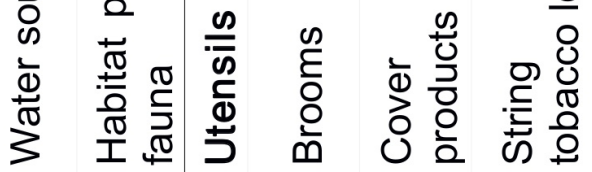




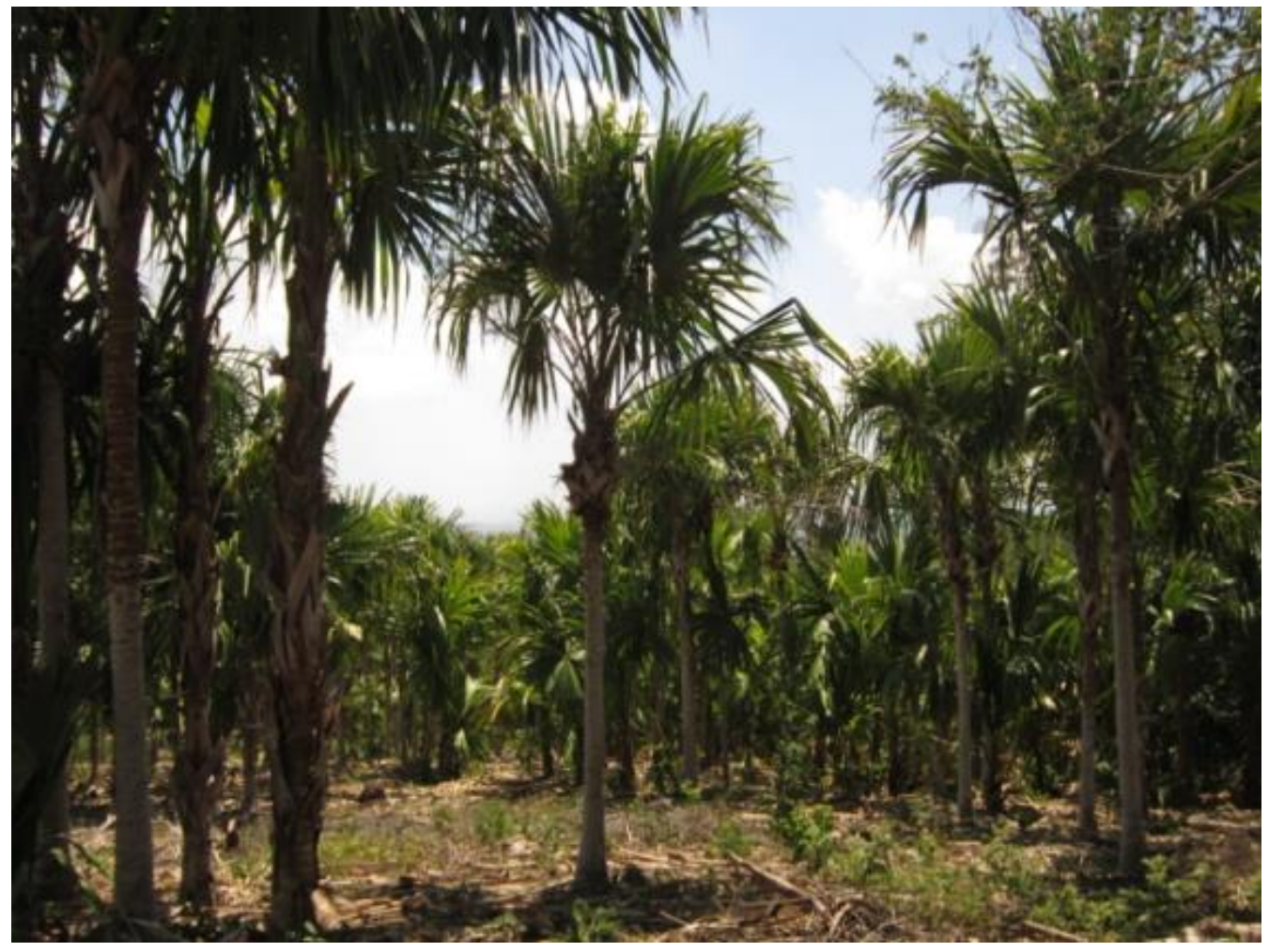

Figure 4. General aspects of a property with Sabal mauritiformis palm exploitation. Farm of Mr. Bernardo Sulbarán, Piojó, Colombia. Photo: Ana Estupiñán-González.

$(\geq 10000)$, the harvesters hire an assistant, often a relative, who helps in cutting, trimming, and tieing up the bundles. In 2014, a harvester's income was around USD 11 for each day of work.

Traders are intermediaries between the palm owners and the final users. In all cases, the commercial process is arranged through a verbal agreement and the traditional marketing unit is a batch of one thousand leaves. In 2014, producers sold a batch at an average price of 116 USD and paid the harvester an average of 33 USD for cutting and bundling the leaves. According to the producers, income derived from leaf trade has always been complementary to that obtained through other agricultural activities. Only one producer claimed to obtain all of his income from his work with the palm.

Leaf merchants have small collection centers at their homes, with room for storing up to 3,000 leaves. No larger quantities are collected, because leaves become fragile if not used within two months after harvest. According to statements we collected, work as merchants began ca. 30 years ago. In our study area there were only two people

Table 2. Annual production, number and type of producers of Sabal mauritiiformis leaves in Piojó (Atlántico), Colombia.

\begin{tabular}{ccc}
\hline Type of producer & Total production (leaves/year) & Number of producers \\
\hline Small & $<2000$ & 11 \\
Medium & $2000-5000$ & 10 \\
Large & $5000-10000$ & 6 \\
Very Large & $>10000$ & 3 \\
\hline Total & & 30 \\
\hline
\end{tabular}


devoted to this trade, and in 2014 they got 33-66 USD per leaf batch.

On average, more than one half of the Sabal-thatched constructions in the overall study area were used in commercial activities (Figures 6,7), but figures varied within the area. Whereas on the beaches of Juan de Acosta more than $90 \%$ of the owners of palm-thatched constructions associated their commercial activities with tourism, in Piojó only $40 \%$ of the owners associated their buildings with commercial activities, the remainder corresponding to housing needs.

Interviewees stated that roofs could last for 20-26 years, with occasional maintenance. At Santa Verónica beach, environmental factors such as humidity and sea breezes were associated with the deterioration of roofs. Maintenance includes the replacement of leaves from the top of the roof and the use of insecticides to control termites or moths. Users agreed that placing a polyethylene mesh on the thatch and applying a mixture of varnish, insecticide and shellac to the leaves, once the thatching is finished, reduces the negative effect of sea breeze, giving a better look to the roof and increasing its durability.

\section{Local ecological knowledge and management}

Most producers and harvesters identified

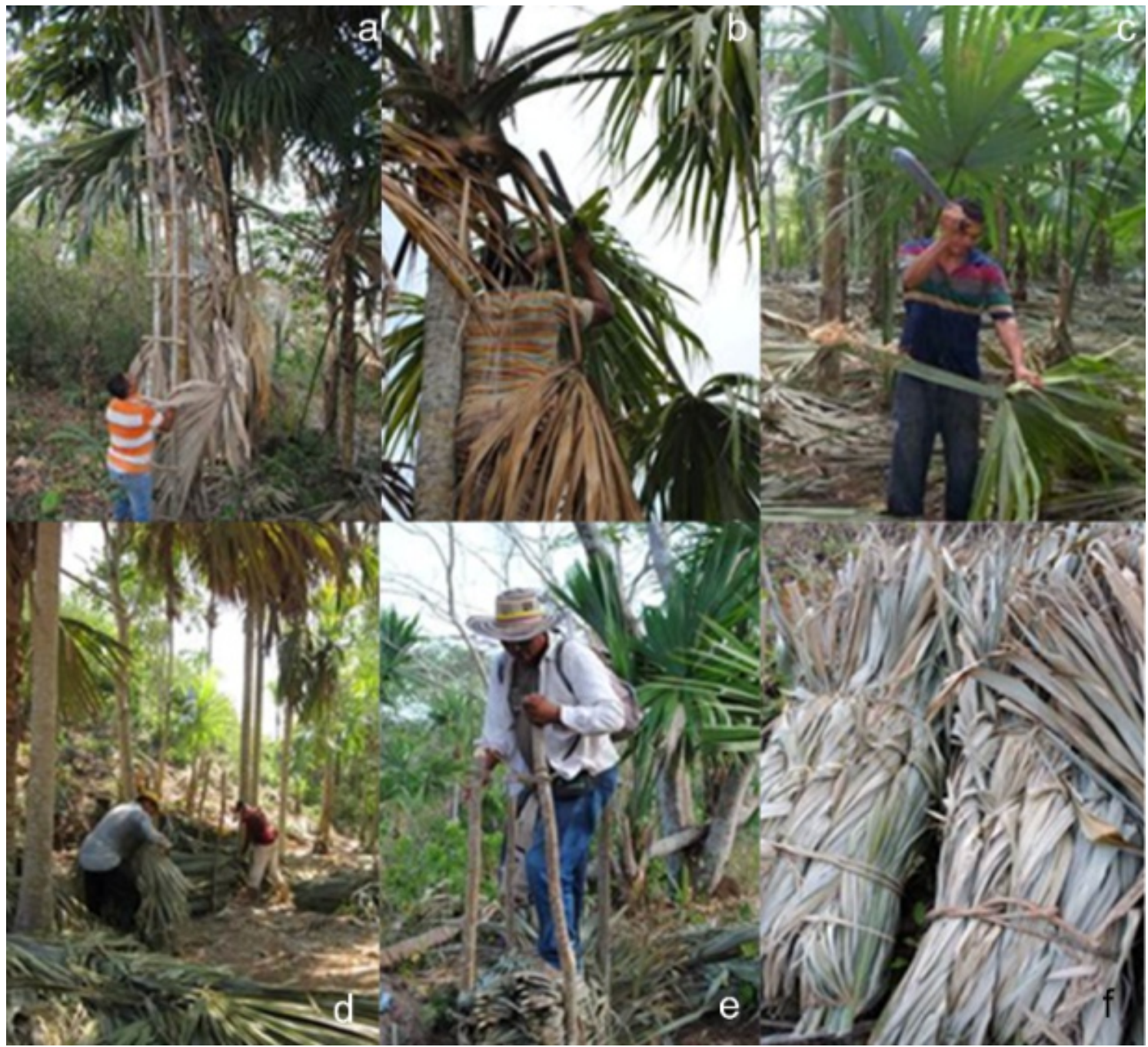

Figure 5. Harvest of Sabal mauritiformis leaves in Colombian Caribbean. a-b, cutting; c. trimming the petioles; d-f, tieing up the bundles. Photos: Ana Estupiñán-González. 
the environmental conditions and factors that influence distribution and mortality in $S$. mauritiiformis. Fire was underlined as one of the major drivers of mortality for individuals of all sizes. Drought and livestock grazing were listed as the main causes of mortality for young, acaulescent palms. For stemmed individuals, termites (Insecta: Isoptera), wind, lightning and leaf cutting during new moon were listed as the main death causes (Figure 8a). Producers claimed that harvesting is not carried before the fifth day of crescent, locally called the fifth of moon (el quinto de luna). Other stakeholders claimed that leaves harvested during that period deteriorate rapidly, and insect larvae quickly invade the roofs, reducing their quality and duration.

Fresh sites on hills, and the margins of streams and creeks were recognized by informants as places where the palms thrive and become abundant. The palm is considered by local people as a highly drought-tolerant species, once it becomes established (Figure 8b).

Both farm owners and harvesters are aware that seeds are the only source of reproduction of the species. In their statements, the interviewees considered that it was not necessary to use any treatments

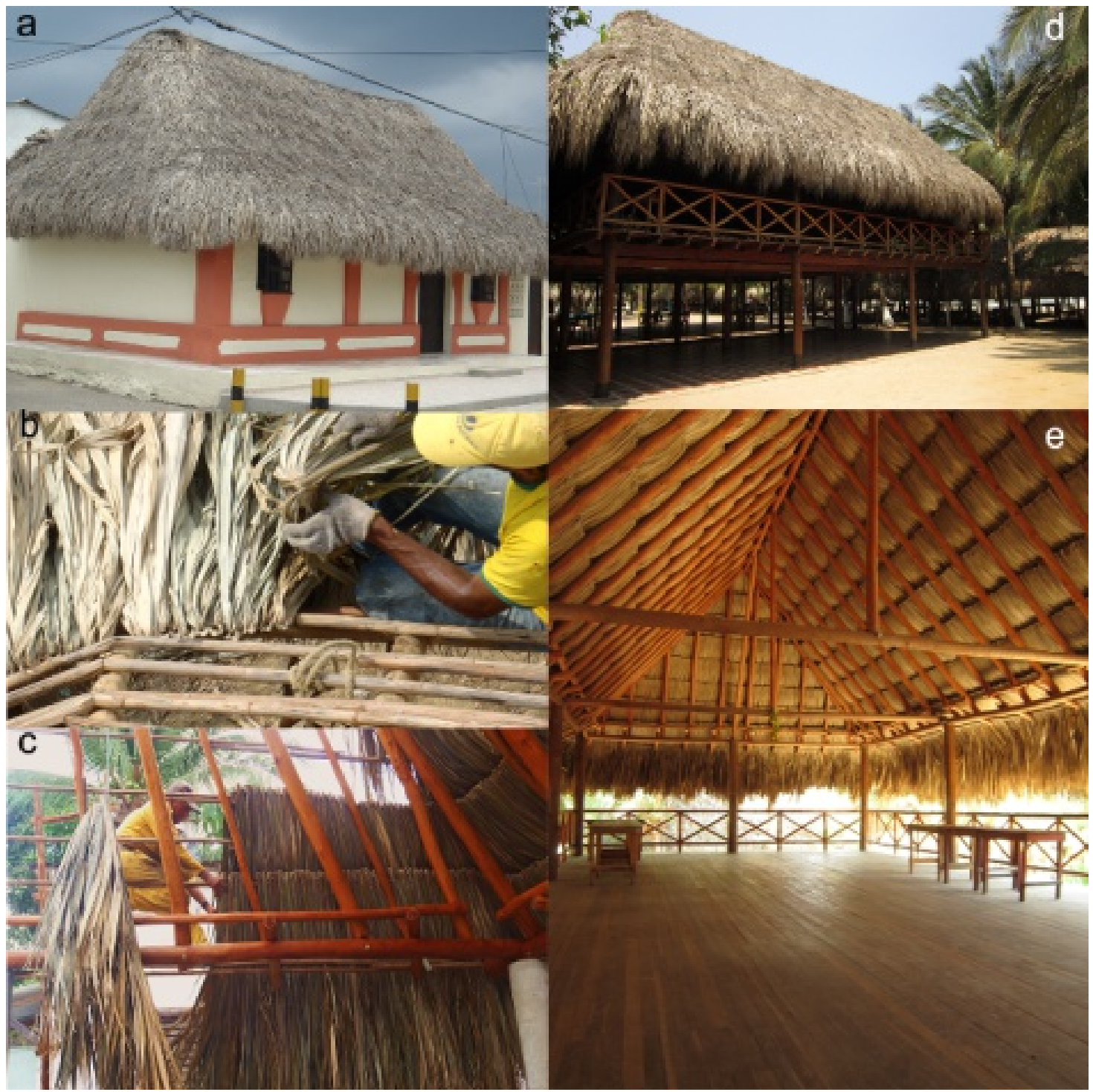

Figure 6. Thatching with leaves of Sabal mauritiiformis in Colombian Caribbean. a, home; b-c, thatching process; d-e, beach restaurant. Photographs: a, b, c, Viviana Andrade-Erazo; d, e, Ana Estupiñán-González. 


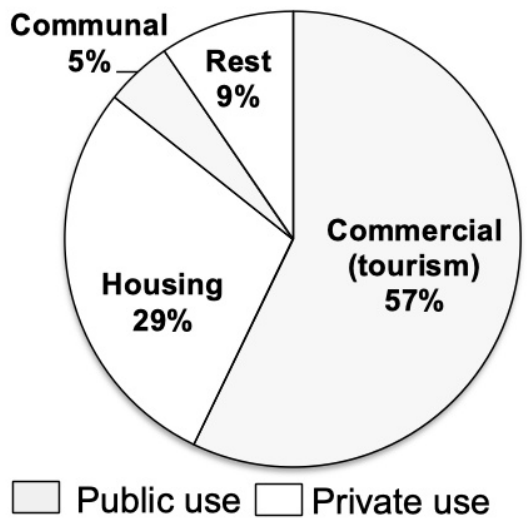

Figure 7. Uses of Sabal mauritiiformis thatches in Colombian Caribbean.

to induce germination. They also agreed that flowering takes place during first semester (March-June) and fruiting during the second one (July-September) (Figure 8c).

All palm groves visited were the result of tolerance to the palms, when the natural vegetation was eliminated through slash and burn for farming. Crop or livestock production is carried out directly by the owners, or by landless peasants allowed to use a part of the farm for cultivation, in exchange for eliminating the arboreal and shrubby vegetation of these areas. Thus, the owner benefits from the cleaning of an area that can later be used for pastures or new subsistence crops, while the landless peasant obtains a harvest that contributes to his food security. The farmers stated that the palms are not cut down, because they are of economic interest; that is why the palms become a part of the agricultural landscape, under the characteristic structure of agroforestry systems. Interviewees also listed other forms of non-selective in situ management and occasional ex situ cultivation, ranging from the promotion and protection of palm populations to the sowing of palms in areas other than those originally occupied by them in the property (Figure 9 ).
Promotion practices included the occasional burying of complete infructescences at sites devoid of palms. In addition, they protected and transplanted seedlings that had emerged spontaneously, in order to increase palm populations. Seed germinators and fertilization were marginal practices carried out only at one site each. Another promotional activity was pruning the old and senescent leaves of young palms, the purpose being to accelerate the growth of the individuals so that these reach the appropriate size to be harvested commercially (Figure 9).

Maintenance and protection was carried out by the search and removal of aggregations of leaf-eating caterpillars (probably Brassolis sp.) and the elimination of termite mounds (Insecta: Isoptera). The application of synthetic insecticides and acaricides to reduce populations of ticks and termites was part of the chemical control reported by the interviewees. Other protective activities were fencing, and shifting cattle among lots in the property, in order to control and reduce both herbivory and trampling of acaulescent palms.

Weed control is also common, but it is aimed at facilitating mobility of harvesters and promoting the establishment of pastures in the farm, rather than at protecting the palm populations themselves. The farmers stated that they avoid damaging seedlings or small palms during this work, except in a few cases, when herbicides or fire were used for weed control. Only at $17.3 \%$ of the palm-leaf producing farms is the use of fire in palm groves strictly avoided; in other farms, burning is carried out partially or at irregular time intervals (Figure 9). 


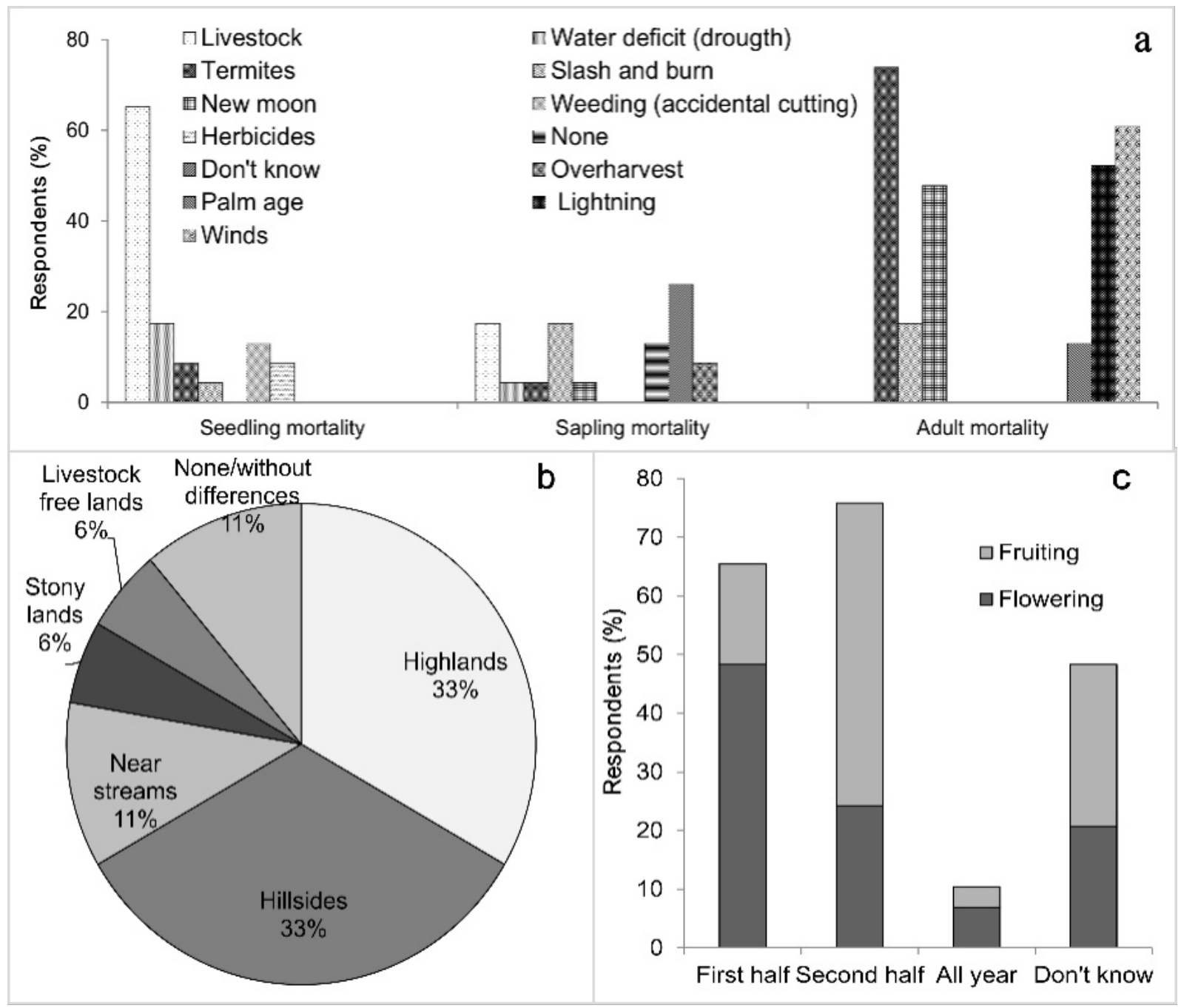

Figure 8. Local ecological knowledge of the palm Sabal mauritiiformis in Piojó, Atlántico, Colombia. a: factors associated with mortality; b, appropriate environmental conditions for the development of palm groves; c, periods of flowering and fruiting during the year.

\section{DISCUSSION}

\section{Sociocultural importance of Sabal mauritiiformis}

Sabal mauritiiformis has a great economic and cultural value in the Colombian Caribbean, and is the base of a regional market that generates cash income for villagers. This situation is not uncommon to other palm species, which are preserved and managed in anthropized systems because their products represent an economic profit (Bernal et al. 2011; Torres 2013; García et al. 2011; García-Amado et al. 2013). On the other hand, beyond strengthening the economy of many families, the multiple uses recorded here for other vegetative and reproductive structures evidence the relevance of this species for rural communities. This situation resembles the one described by Bernal et al. (2010) for the large palm Attalea butyracea (Mutis ex L.f.) Wess.Boer, which is also common in many areas of the Caribbean lowlands of Colombia, and is also a priced thatching material with many subsidiary uses.

Elsewhere, similar situations have been 
reported for other palm species such as Attalea phalerata Mart. ex Spreng. and Geonoma deversa (Poit.) Kunth in the Bolivian Amazon (Reyes-García et al. 2006), Borassus flabellifer L. in India (Jambulingam and Fernandes 1986) and Arenga pinnata (Wurmb) Merr. in Indonesia (Mogea et al. 1991). In all cases, the multipurpose profile of these species makes them potential plants for planning productive systems integrating native biodiversity and conservation.

The wide range of resources of $S$. mauritiiformis and its incorporation into agricultural systems evidence the need for further research on this species, leading to the development of appropriate production models for the whole Caribbean region. The systems traditionally followed in Piojó make this area an excellent starting point.

The cultural significance of $S$. mauritiiformis in the Caribbean region of Colombia is evident in many aspects of everyday life. These include Sabal leaves used as the preferred wrapping for the "bollo de yuca", a priced dough made of manioc; Sabal-thatched public buildings used as meeting places for strengthening social cohesion; and the Sabal mauritiiformis
Festival (Festival del la palma amarga), annually held in Piojó and involving the inhabitants of nearby towns.

\section{Ecological knowledge and management}

All people interviewed reported that thatching with $S$. mauritiiformis leaves was already a common practice long ago. Producers, harvesters and traders reminded that they lived in homes thatched with palms and that their parents also did work with palm populations. As early as the mid-19th century, Karsten (1856) recorded thatching as the most important use of this species. This long history of direct contact with $S$. mauritiiformis through its utilization has led to an accumulation of detailed knowledge about the palm's natural history by stakeholders of the value chain. This is reflected in the recognition of the physicalbiotic variables associated with the palm's distribution, its reproductive seasons, and mortality factors.

A similar situation was recorded by Joyal (1996), who showed that direct contact of local people with Sabal uresana Trel. was determinant for the amount and quality of

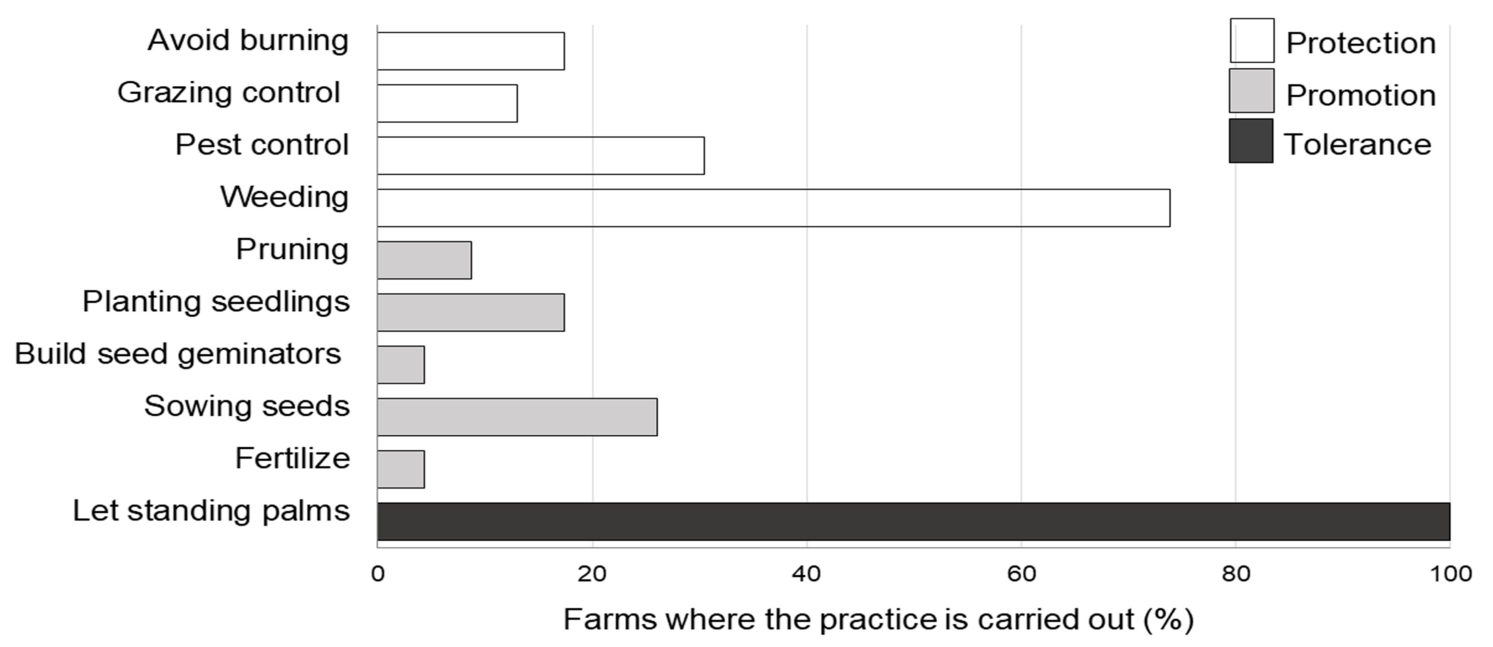

Figure 9. Management actions of Sabal mauritiformis palm groves in Piojó Atlántico, Colombia. 
information provided by informants in Sonora, Mexico. For this species and Sabal pumos (Kunth) Burret (Aguilera-Taylor 2009), rural inhabitants in Mexico stated that fire, livestock, herbicides and excess of leaf harvest were factors negatively affecting palms in different developmental stages. Traditional ecological knowledge of rural communities in the Caribbean appears to be shared among people that use Sabal leaves, and provides evidence of common management of these species throughout a relatively broad area. However, in several cases the roughness of answers or the manifest unawareness of the interviewees about of the species ecology must be taken with some alarm. Several authors have shown that an intensification of NTFP trade can lead to an overexploitation of the species and to the erosion of traditional knowledge about ecology and management of the species that provide them (Schreckenberg and Marshall 2006; Belcher and Schreckenberg 2007; Ticktin and Johns 2002; Wiersum et al. 2014).

As with other Sabal species in the Caribbean region (Joyal 1996; Caballero et al. 2001; Martínez-Ballesté et al. 2006; Aguilera-Taylor 2009), the tolerance of $S$. mauritiiformis in agroforestry systems of Piojó can be interpreted as a strategy of multiple forest use developed by indigenous and peasant communities (Toledo et al. 2003). This emphasizes an adaptive pattern articulating subsistence agriculture and the production of marketable goods in landscapes of vegetation mosaics, where several successional stages occur simultaneously. At the same time, this system involves conservation of the knowledge required for the management of these scenarios (Berkes et al. 2000; Toledo et al. 2003).

Management of $S$. mauritiiformis can be considered intensive (Blancas et al. 2013; González-Insuasti and Caballero 2007) because of the number of actions and the specialization degree of tasks performed to obtain the resource. These actions include planting seeds and transplanting seedlings, in addition to protective actions against herbivores. The economic and cultural importance of $S$. mauritiiformis in Piojó is the main driver determining the intensity of management (Blancas et al. 2016), which is often aimed at ensuring or increasing the availability of the resource. However, although in all palm groves studied the leaves are used for trade, most protection or promotion actions are carried out only by less than $30 \%$ of the owners of these palm groves. This may be because $S$. mauritiformis is considered an abundant resource, resilient to disturbances as fire or drought, and able to regenerate without human intervention.

Here, we show that management of $S$. mauritiiformis in Piojó exemplifies the maximization of resources in a socialecological system (Albuquerque et al. 2019). The complexity of that management reveals the importance of $S$. mauritiiformis in the Colombian Caribbean, and it could explain why its use has persisted despite forest disappearance, and why the palm has become central in the physiognomy of local productive systems. These practices aim at decreasing energy invested in leaf harvest through wide areas, and extra monetary costs derived from the use of other, shorterlasting thatching materials.

\section{Socio-economic context of utilization of leaves}

Change in the use of $S$. mauritiiformis leaves in the Colombian Caribbean coast from a scenario of self-supply, in which this 
resource was used for thatching houses, towards a more commercially oriented use is evident in the proliferation of palm-thatched constructions for recreation and tourism activities in coastal locations. GambaTrimiño and Benavides (2013) noticed this trend on the beaches of the village of Guachaca, near Santa Marta; in the Fauna and Flora Flamingos Sanctuary, near Riohacha; in Cartagena, and in El Dique region. On the other hand, palm-thatched houses have become less popular and often are restricted to rural areas close to Sabal stands, as in El Paso, Chimichagua, Bosconia, in César, and La Garita, El Beque and San Antonio, in Sincelejo, Sucre (Gamba-Trimiño and Benavides 2013). A similar situation has been described for Sabal yapa in Mexico (Caballero et al. 2004), where tourism has also shaped palm management.

There is a social paradox in the process, though. In the past decades, the more affluent families in the Caribbean villages progressively replaced their palm-thatched roofs for tin roofs (Fernández 2011), which are hot under the sun and noisy under the rain, but were considered as a symbol of higher status. People using Sabal roofs were regarded as poor. With the advent of tourism and the new status gained by palm thatches, some people long for the fresher and quieter Sabal thatch, but the price of leaves is now too high for them to be able to afford one. Market forces deprived them of a traditional resource.

Three aspects characterized the value chain of $S$. mauritiformis leaves: the development of specialized works, like those of harvesters and palm thatchers; the divergence between areas of leaf production and areas of use; and the configuration of different scenarios for their use. However, unlike other species of wild palms, which include stakeholders in multiple levels (e.g., Valderrama 2011; Marshall et al. 2006), the value chain of $S$. mauritiiformis leaves has a simple structure. The leaves are not transformed before their use, and trade occurs only at a regional scale. However, as with other Colombian palm products and other NTFPs in general, the value chain is based on the traditional knowledge of the communities that use the resource (te Velde et al. 2006; Valderrama 2011).

Both the consolidation of social groups that make a living from the commercial exploitation of $S$. mauritiiformis, and the emergence of lasting markets are indicators of an intensive harvest (Joyal 1996). Although this brings benefits to local people, it can also lead to situations of overexploitation, speculation, unequal markets, and resource shortages. An example of this was recorded for Brahea sp. in southern Mexico (Rangel-Landa et al. 2014), where the differences between the profits received by harvesters-artisans and hat merchants were very high. Although we did not see these situations in the value chain of $S$. mauritiiformis, there were no agreement among users on the more appropriate mechanisms for its utilization. Such mechanisms should include intervals between harvests, management practices, quantities harvested, and sale prices. Lack of this type of consensus represents a vulnerability of this chain in the face of decisions that might be imposed by the stakeholders, speculators, or big capitals, or contingencies such as environmental phenomena. Current legal regulations of harvest, represented in the payment of fees to environmental authorities, do not contribute to improving palm management. This was evident in the overall lack of knowledge of stakeholders about this topic. This suggest that sheer legislation is not 
enough to improve people-nature relations.

Moreover, the intensification of leaf extraction due to a growing demand could lead to the local extinction of the species if the palm's vital rates, like recruitment, survival and growth, were altered (Ticktin 2004; Guariguata et al. 2008; Caballero et al. 2001; Bernal et al. 2010). Although palm populations in Piojó are stable and leaf harvest does not have a negative effect (Andrade-Erazo et al. in preparation), factors such as fire, livestock and overharvesting might affect individuals and jeopardize the future availability of the resource, particularly if long-term production is not planned.

\section{CONCLUSIONS}

The different uses that are given to the vegetative and reproductive parts of $S$. mauritiiformis, together with the cultural importance that it has for people, allow the palm to be recognized as a multipurpose species offering a great diversity of resources and with a high potential to be integrated into agricultural production systems. Furthermore, the growing popularity of the leaves for thatching kiosks and other tourism infrastructure in the Caribbean beaches is an appropriate scenario for strengthening the value chain of this resource, maintaining direct interaction among actors and promoting the rational use of this resource. In addition, knowledge about environmental factors, both those that favor the development and persistence of palm groves and those that affect them, are a valuable tool that must be taken into account in planning the management of this resource by stakeholders in the value chain. It is essential to promote and strengthen those practices that contribute to guarantee the future availability of the resource. This includes the establishment of new palm groves under agroforestry arrangements that integrate other useful species, management to minimize the effects of harmful environmental factors, protection against browsing, and the regulation of other harmful practices, like burning.

\section{ACKNOWLEDGEMENTS}

The authors are grateful for the funds of the Programa Paisajes de Conservación of the Fundación Patrimonio Natural, through the financing of the project "Formulation of management plans and sustainable use of promising palms of the Caribbean region that contribute to a strategy of use of natural resources of the dry forest tropical". Likewise, we are grateful for the support of the Division de Investigación (DIB) of the National University of Colombia, Bogotá, which supported the subproject "Use and management of the bitter palm (Sabal mauritiiformis) in Piojó, Atlántico, Colombia" (Code 20381). Special thanks to the inhabitants of the municipalities of Piojó, Juan de Acosta and in general of the Colombian Caribbean for all the collaboration and knowledge that we received during the field phase. We thank to the members of the Neotropical Wild Palms Research Group, Dr. José Juan Blancas Vásquez and two anonymous reviewers for their valuable comments that helped to improve the manuscript.

\section{DATA AVAILABILITY}

The data used to support the findings of this study are available from the corresponding author upon reasonable request. 


\section{CONFLICTS OF INTEREST}

The authors have no conflicts of interest to declare.

\section{CONTRIBUTION STATEMENT}

Conceived the research project and fieldwork: VA, ACEG, RB, GG.

Collected and systematized general data, wrote the first draft: VA, ACEG.

Carried out the data analysis and reviewed several drafts of the manuscript: VA, ACEG, NG, RB, LR, GG.

Concluded the final version of this paper: VA, NG, RB.

All authors read and approved the final manuscript.

\section{REFERENCES}

Aguilera-Taylor I (2009). Manejo sostenible de Sabal pumos: bases demográficas y sociales. MSc. Dissertation, Universidad Michoacana de San Nicolás de Hidalgo, Morelia, Michoacán, México

Aguilera-Taylor I, Domínguez AC, Muñoz-Castro G, López-Hoffman L (2007). Servicios ambientales de una palma endémica: su importancia para la población rural. Gaceta Ecológica 84-85:75-84

Albuquerque UP, Ramos, MA, Lucena, RFP, Alencar, NL (2014). Methods and techniques used to collect ethnobiological data. In: Albuquerque UP, Cunha LFVC, Lucena RFP, Alves RRN (eds) Methods and Techniques in Ethnobiology and Ethnoecology. Springer, New York, pp. 39-64

Albuquerque UP, Medeiros PM, Ferreira WS, Silva TC, Vasconcelos RR, Gonçalves-Souza T (2019). Social-Ecological Theory of Maximization: Basic Concepts and Two Initial Models. Biological Theory 14: 73-85

Andrade-Erazo V, Galeano G (2016). La palma amarga (Sabal mauritiformis, Arecaceae) en sistemas productivos del caribe colombiano: estudio de caso en Piojó, Atlántico. Acta Biológica Colombiana 21(1):141-150
Antweiler C (1998). Local knowledge and local knowing an anthropological analysis of contested "cultural products" in the context of development. Anthropos 93:469-49

Anzellini-García-Reyes M, Garcia-Reyes Röthlisberger MI (2016). Técnicas Vernáculas. Catálogo de arquitectura vernácula con palmas en el Caribe colombiano. AGRA Arquitectos y Fondo Patrimonio Natural, Bogotá, Colombia

Arnold JE, Ruiz M (2001). Can non-timber forest products match tropical forest conservation and development objectives?. Ecological Economics 39:437-447

Blancas J, Casas A, Pérez-Salicrup D, Caballero $J$, Vega $E$ (2013). Ecological and sociocultural factors influencing plant management in Náhuatl communities of the Tehuacán Valley, Mexico. Journal of Ethnobiology and Ethnomedicine 9:1-39

Blancas J, Casas A, Moreno-Calles Al, Caballero J (2016). Cultural motives of plant management and domestication. In: Lira R, Casas A, Blancas J (eds) Ethnobotany of Mexico: interactions of people and plants in Mesoamerica. Springer, New York, pp. 233-256

Belcher B, Schreckenberg K (2007). Commercialisation of non-timber forest products: A reality check. Development Policy Review 25(3):355-377

Berkes F, Colding J, Folke C (2000). Rediscovery of traditional ecological knowledge as adaptive management. Ecological Applications 10(5):1251-1262

Bernal R, Galeano G, García N, Olivares IL, Cocomá C (2010). Uses and commercial prospects for the wine palm, Attalea butyracea, in Colombia. Ethnobotany Research and Applications 8:255-268

Bernal R, Torres C, García N, Isaza C, Navarro J, Vallejo M, Balslev H (2011). Palm management in South America. Botanical Review 77:607-646

Bernard, HR (2011). Methods in Antropology: Qualitative and Quantitative Approaches. 5th ed. Altamira Press, Plymouth, UK

Betancourt-A A (2008). Reconstrucción paleoecológica del Holoceno en la ciénaga de Luruaco. Cambios medioambientales y procesos humanos de adaptación. MSc. Dissertation, Universidad Nacional de Colombia, Bogotá, Colombia 
Brokamp G, Mittelbach M, Valderrama N (2010). Obtención de datos sobre producción y comercialización de productos de palmas. Ecología en Bolivia 45(3):69-84

Caballero J, Casas A, Cortés L, Mapes C (1998). Patrones en el conocimiento, uso y manejo de plantas en pueblos indígenas de México. Revista de Estudios Atacameños 16:181-196

Caballero J, Martínez-Ballesté A, Gama V (2001). El uso y manejo tradicional de la palma de guano en el área maya de Yucatán. Conabio-Biodiversitas 39:1-6

Caballero J, Pulido M, Martínez-Ballesté A (2004). El uso de la palma de guano (Sabal yapa) en la industria turística de Quintana Roo, México. In: Alexiades M, Shanley P (eds) Productos forestales, medios de subsistencia y conservación. Estudios de caso sobre sistemas de manejo de productos forestales no maderables. Center for International Forestry Research (CIFOR). Bogor-Desa Putera, pp. 365385

Carsucre, Cudesac (2007). Plan de Manejo de la Palma Amarga. Corporación Unificada para el Desarrollo Ecológico, Económico, Social y Ambiental de Colombia- Corporación Autónoma Regional de Sucre, Sucre, Colombia

Carvalho A, Frazão-Moreira A (2011). Importance of local knowledge in plant resources management and conservation in two protected areas from Trás-os-Montes, Portugal. Journal of Ethnobiology and Ethnomedicine 7:36

Casas A, Otero-Arnaiz A, Pérez-Negrón E, Valiente-Banuet A (2007). In situ management and domestication of plants in Mesoamerica. Annals of Botany 100(5):1101-1115

Charnley S, Fischer AP, Jones ET (2007). Integrating traditional and local ecological knowledge into forest biodiversity conservation in the Pacific Northwest. Forest Ecology and Management 246:14-28

Cruz MP, Estupiñán-G AC, Jiménez-Escobar ND, Sánchez N, Galeano G, Linares E (2009). Etnobotánica de la región tropical del Cesar, Complejo Ciénaga de Zapatosa. In: Rangel-Ch JO (ed) Colombia diversidad biótica VIII, Media y baja montaña de la Serranía del Perijá. Universidad Nacional de Colombia-Instituto de Ciencias Naturales-CORPOCESAR, Bogotá, pp. 417-447
Estupiñán-González AC (2012). Conocimiento tradicional y uso efectivo de las palmas nativas en una comunidad campesina del Caribe colombiano. MSc. Dissertation, Universidad Nacional de Colombia, Bogotá, Colombia

Fals-Borda O (1979). Fundamentos de la cultura anfibia. La presencia indígena. In: Fals-Borda (ed) Historia Doble de la Costa. Tomo I. Mompox y Loba. El Áncora Editores, Bogotá, Colombia, pp. 30A-43A

Fals-Borda O (1986). La amachada conquista del Sinú. In: Fals-Borda (ed) Historia Doble de la Costa. Tomo IV. Retorno a la Tierra. El Áncora Editores, Bogotá, Colombia, pp. 30A-52a

Fernández J (2011). Arquitectura provincial en el departamento del Atlántico. Divulgaciones etnológicas 1: 36-56

Galeano G, Bernal R (1987). Las Palmas del Departamento de Antioquia. Región Occidental. Universidad Nacional de Colombia, Centro Editorial, Bogotá.

Galeano G, Bernal R (2010). Palmas de Colombia. Guía de Campo. Instituto de Ciencias Naturales - Facultad de Ciencias Universidad Nacional de Colombia, Bogotá, Colombia

Galeano G, Bernal R, Figueroa Y (2015). Plan de conservación, manejo y uso sostenible de las palmas de Colombia. Ministerio de Ambiente y Desarrollo Sostenible - Universidad Nacional de Colombia, Bogotá, Colombia

Gallardo G (2013). Evaluación del potencial turístico de las playas del Departamento del Atlántico-Colombia, desde la perspectiva ambiental. Dimensión Empresarial 11:62-69

Gamba-Trimiño C, Benavides K (2013). Usos, mercados, aprovechamiento en sistemas integrados. Diagnóstico base de cuatro especies: palma estera (Astrocaryum malybo), palma de vino (Attalea butyracea), uvita de lata, corozo de lata, lata (Bactris guineensis) y palma amarga (Sabal mauritiiformis). Technical document, Fondo Patrimonio Natural, Bogotá, Colombia

García N, Torres MC, Bernal R, Galeano G, Valderrama N, Barrera VA (2011). Management of the spiny palm Astrocaryum malybo in Colombia for the production of mats. Palms 55(4):190-199 
García-Amado LR, Pérez MR, Dahringer G, Escutia FR, García SB, Mejía EC (2013). From wild harvesting to agroforest cultivation: A Chamaedorea palm case study from Chiapas, Mexico. Forest Policy and Economics 28: 44-51

Gómez-Amador A (2003). La palma en la arquitectura. ASINEA 22:109-118

González-Insuasti MS, Martorell C, Caballero J (2008). Factors that influence the intensity of non-agricultural management of plant resources. Agroforestry Systems 74:1-15

González-Insuasti MS, Caballero J (2007). Managing plant resources: How intensive can it be? Human Ecology 35:303-314

Guariguata MR, Cronkleton P, Shanley P, Taylor PL (2008). The compatibility of timber and non-timber forest product extraction and management. Forest Ecology and Management 256:1477-1481

IDEAM, IGAC, IAvH, INVEMAR, SINCHI, IIAP (2007). Ecosistemas continentales, costeros y marinos de Colombia. Instituto de Hidrología, Meteorología y Estudios Ambientales, Instituto Geográfico Agustín Codazzi, Instituto de Investigación de Recursos Biológicos Alexander von Humboldt, Instituto de Investigaciones Ambientales del Pacifico Jhon Von Neumann, Instituto de Investigaciones Marinas y Costeras José Benito Vives de Andreis, Instituto Amazónico de Investigaciones Científicas Sinchi, Bogotá, Colombia

IDEAM -I nstituto de Hidrología, Meteorología y Estudios Ambientales (2014). Atlas climatológico de Colombia 1981-2010. [http:// atlas.ideam.gov.co/visorAtlasClimatologico.html] Accessed 23 march 2019

IGAC (Instituto Geográfico "Agustín Codazzi”) (1977). Zonas de vida o formaciones vegetales de Colombia. Instituto Geográfico "Agustín Codazzi", Bogotá, Colombia

Isaza C, Galeano G, Bernal R (2014). Manejo actual del asaí (Euterpe precatoria Mart.) para la producción de frutos en el sur de la Amazonia colombiana. Colombia Forestal $17: 77-99$

Jambulingam R, Fernandes EC (1986). Multipurpose trees and shrubs on farmlands in Tamil Nadu State (India). Agroforestry Systems 4:17-32
Jiménez-Escobar ND, Estupiñán-González AC (2011). Useful trees of the Caribbean region of Colombia. Bioremediation, Biodiversity and Bioavailability 5:65-79

Jiménez-Escobar ND, Albuquerque UP, RangelCh O (2011). Huertos familiares en la Bahía de Cispatá, Córdoba, Colombia. Bonplandia 20(2): 309-328

Joyal E (1996). The palm has its time: an ethnoecology of Sabal uresana in Sonora Mexico. Economic Botany 50(4):446-62

Kaplinsky R, Morris M (2002). A Handbook for Value Chain Research. Report prepared for IDRC, Ottawa, Canada

Karsten H (1856). Plantae Columbianae. Linnaea 28: 241-282

Macía M, Armesilla J, Cámara-Leret $R$, Paniagua-Zambrana N, Villalba S, Balslev $\mathrm{H}$, Pardo-de-Santayana M (2011). Palm uses in northwestern South America: a quantitative review. The Botanical Review 77(4):462-570

Marshall E, Schreckenberg K, Newton AC (eds) (2006). Commercialization of Non-timber Forest Products: Factors Influencing Success. Lessons Learned from Mexico and Bolivia and Policy Implications for Decisionmakers. UNEP World Conservation Monitoring Centre, Cambridge, UK

Martínez-Ballesté A, Martorell C, Caballero J (2006). Cultural or ecological sustainability? The effect of cultural change on Sabal palm management among the lowland Maya of Mexico. Ecology and Society 11:27

Mayan M (2001). Una Introducción a los métodos cualitativos. Módulo de entrenamiento para estudiantes y profesionales. [http://www.ualberta.ca/ iiqm/ pdfs/introduccion.pdf]. Accesed 15 March 2015

Mogea J, Seibert B, Smits W (1991). Multipurpose palms: the sugar palm (Arenga pinnata (Wurmb) Merr.). Agroforestry Systems 13:111-129

Moreno S, Sánchez C, Galeano G, Salazar J, Barrios LJ (1993). Cubiertas vegetales y maderables para la región húmeda de La Guajira. SENA-Universidad Nacional de Colombia, Bogotá, Colombia 
Pérez M, Rebollar S (2003). Anatomía y usos de las hojas maduras de tres especies de Sabal (Arecaceae) de la Península de Yucatán, México. Revista de Biología Tropical 51(2):333-344

Rangel-Landa S, Rivera-Lozoya E, Casas A (2014). Uso y manejo de las palmas Brahea spp. (Arecaceae) por el pueblo ixcateco de Santa María Ixcatlán Oaxaca, México. Gaia Scientia 8:62-78

Raymond CM, Fazey I, Reed MS, Stringer LC, Robinson GM, Evely AC (2010). Integrating local and scientific knowledge for environmental management. Journal of Environmental Management 91:1766-1777

Reyes-García V, Huanca T, Vadez V, Leonard W, Wilkie D (2006). Cultural, practical and economic value of wild plants: a quantitative study in the Bolivian Amazon. Economic Botany 60:62-74

Schreckenberg K, Marshall E (2006). Access rights and resources: The impacts of NTFP commercialization. In: Marshall E, Schreckenberg K, Newton AC (eds) Commercialization of Non-timber Forest Products: Factors Influencing Success. Lessons Learned from Mexico and Bolivia and Policy Implications for Decision-makers UNEP World Conservation Monitoring Centre, Cambridge, UK, pp.81-88

SENA: Servicio Nacional de Aprendizaje (1990). El Bahareque en la región del Caribe. Fondo Nacional de Formación Profesional para la Industria de la Construcción -FIC, Bogotá, Colombia te Velde DW, Rushton J, Schreckenberg K, Marshall E, Edouard F, Newton A, Arancibia E (2006). Entrepreneurship in value chains of non-timber forest products. Forest Policy and Economics 8:725-741

Ticktin T (2004). The ecological implications of harvesting non-timber forest products. Journal of Applied Ecology 41:11-21

Ticktin T, Johns T (2002). Chinanteco management of Aechmea magdalenae: implications for the use of TEK and TRM in management plans. Economic Botany 56:177191

Toledo VM, Ortiz-Espejel B, Cortés L, Moguel P, Ordoñez MDJ (2003). The multiple use of tropical forests by indigenous peoples in Mexico: a case of adaptive management. Conservation Ecology 7:9

Torres I, Casas A, Delgado-Lemus A, Vega E, Martínez-Ramos M (2015). Population dynamics and sustainable management of mescal agaves in Central Mexico: Agave potatorum in the Tehuacán Cuicatlán Valley. Economic Botany 69:26-41

Torres MC (2013). Sará (Copernicia tectorum) In: Bernal R, Galeano G (eds) Cosechar sin destruir: aprovechamiento sostenible de palmas colombianas. Facultad de Ciencias-Instituto de Ciencias Naturales, Universidad Nacional de Colombia. Bogotá, pp. 191-199

Valderrama N (2011). Value Chain Investigations on Four Colombian Palm Species. PhD Thesis, Technische Universität München, Munich, DE.

Wiersum KF, Ingram VJ, Ros-Tonen MAF (2014). Governing access to resources and markets in non-timber forest product chains. Forests, Trees and Livelihoods 23:6-18

Received: 03 March 2020

Accepted: 08 May 2020

Published: 15 May 2020 